\title{
About the kassites also known as the gauls and then gens Cassia
}

\author{
Paola Villani \\ Politecnico di Milano, Transport infrastructures and Geosciences, Dept. of Civil and Environmental Engineering, Milano, Italy
}

\section{Email address:}

paola.villani@polimi.it

\section{To cite this article:}

Paola Villani. About The Kassites Also Known As the Gauls and Then Gens Cassia. International Journal of Archaeology. Vol. 1, No. 1, 2013, pp. 13-25. doi: 10.11648/j.ija.20130101.13

\begin{abstract}
Thanks to the opportunity of highway construction, a deep study has been conducted in order to understand the major influences that the Po Plain area had in the period 1800BC - 400 AD. Lack of basic ground items and a few but constant historical inconsistencies, have driven to a reconsideration of the commonly accepted and disclosed history. The analysis is based on a cross-reading of historical, artistic, literary preexistences, in a timeframe that concerns the period $1800 \mathrm{BC}-400$ A.D. The paper gives a fresh look to the history of the area, from the evolution of Gallia Cisalpina, to the Galatians in Northern Italy and finally to Gens Cassia (previously named Elamites and Kassites) that introduced significant enhancements to the road technology and to transportation thanks to their deep knowledge in horse breeding, carriages con-struction and metalworks. This article incorporates and integrates that which already published in Archaeology 2013, "Re-theorization of the Roads Heritage".
\end{abstract}

Keywords: Roads, Toll Roads, Toponyms, Transportation, Vehicles, Wheels, Wagons, Infrastructure, History, Religion, Language, Dialects, Europe, Asia, Pax Romana, Kassites, Trade, Toll

\section{Introduction}

Cicero asserted "Alterius non sit qui suus esse potest" or "Let him not be another who can be himself" [1] and so identity of each group transcends the centuries and leaves its traces in history, from toponyms to heraldic symbols, from the perpetuation of traditions to language. In two papers [2,3] we have analyzed the data referring to the history roads, the place where according to the ancient king-doms.The opportunity for the text drafting was the request to write the history of that across countryside involved in the construction of a new highway called BREBEMI (Brescia Bergamo - Milano). In this paper has been used a "historical detective" methodology that cannot be described in a short paper. But like in a detective story, lack of basic ground items and a few but constant historical inconsisten-cies have driven to a reconsideration of the commonly ac-cepted and disclosed history. The analysis is based on a cross-reading of historical, artistic, ideogramic symbols and proto-writing, trade and other features of civilization in a timeframe that concerns since of the Intermediate Bronze Age up to 400 A.D.

\section{The Gens Cassia}

\subsection{History of the Area}

The area around Cassano d'Adda has always been crossed by many waterways - in ancient times, such water-ways were necessary resources for watering animals and humans. So far, Egyptians have left an inscription which states: "A way without water is a no-way". Such statement was considered valid in the whole world, regardless of latitude. The Appian Way used to be flanked by a waterway on which passengers were ferried at night and then could continue down the way on the road during the day. Boats used to be towed by mules. Pliny the Elder often refers to water supply points, which were vital places especially concerning Roman Legions displacements. Such places could even turn into real guard castrum or into border crossings points, which were often covered and walled spaces in order to host up to two thousand men. In ancient times, water-ways were very important, since it was possible to transport goods and materials with little effort. Strabo, several times, mentions the transfer of men and goods using river boats and he is concerned to highlight the few rivers in which transport 
could be carried out only with extremely small boats.

Now and then, the intermodal freight transport was important and while, on one side, it allowed goods to be carried effortlessly, on the other side it was, as today, an impedance factor for travel times: as a matter of fact, at that time, sea boats could easily sail up all the wa-terways, such as Adda and Oglio rivers, left-side tribu-tary of the Po river in Lombardy and that did not happen - for example - with Nera, a tributary of the Tiber. Road tolls have not been invented by the Romans. At that time, travelling was a cost and as a matter of fact, a toll was much better and safer than an ambush. The risk was so high as to be often mentioned in declarations and invocations of the Bible with reference to the choice of the right way ${ }^{1}$. Path had to be necessary safe, in order to be the right one. So far, to connect any location to another one, there were at least two different routes. Moreover, if the construction of a "public road" was certainly a source of income (because of the charged toll) to build roads was itself an affordable and assured prosperity to the village. The trade was taxed and constituted a source of considerable revenue. Exact sums in these toll stations were an important asset, and just a small portion was bound to what, nowadays, we classify under the name of "road management" (security, control and maintenance, or costs that resulted from the presence of post stations (mansio)). A well-established theory mentions that among the ancient civilizations, such one of Rome was the first and the only one to create and sustain a steady roads policy for nearly eight centuries, from $300 \mathrm{BC}$ until the fall of the Western empire. We will see togheter how often the history is rewritten in retrospect by those ones who last held the power, and in terms of facts concerning "roads in history", such facts are not exactly the ones that have been handed down. Strabo reports the division of land over ancient times: Traspadana and Cisalpina. This part from Gallia Citeriore was also called Gallia Togata, after which we will explain the definition. Gallia Togata similarly reported as customary name in the text of Jo-annes Georgius Graevius. At that time, North Italy, Provence and Switzerland were lands constituting "Gallia", and the area included between Adda and Oglio was inhabited by the Galli Cenomani so called as well Aulerci.

Over the centuries, such areas were defined as "countries totally subjected to the Rome city". With reference to the presence of Gauls and Romans, there is documentary evi-dence for the city of Verona (Lessini Mountains, inhabited by the Lessoni Gauls). What we shall herewith demonstrate is how the splendor of Rome largely depended on pre-cisely those populations known as Ligurians, Etruscans and Celts, who built the first settlements in Italy.

Because until now, history has been written by those who took the power by force and tried to destroy and completely blur the memory of their predecessors. Old history but that's

\footnotetext{
${ }^{1}$ Bible - Deuteronomy 122 Then all of you approached me and said, 'Let us send men before us, that they may search out the land for us, and bring back to us word of the way by which we should go up and the cities which we shall enter.'
}

worthwhile to explore deeply.

\subsection{Gallia Cisalpina}

First contacts between Rome and Verona are documented as early as the third century BC: it is told there were soon relations of friendship and alliance, but maybe it did not go exactly like that.

Probably the first contacts were right in $390 \mathrm{BC}$, when Gauls of Brennus invaded Rome itself: historians have re-peatedly asserted that the Venets realized the economic benefit of a possible peace treaty and had therefore put pressure on neighboring populations in order to ensure that Gauls came to terms with the Romans. These same histori-ans have conveyed the story that Cenomani Gauls and Ve-nets helped the Romans several times even later, it was "fabricated news" but that will pass into history as errone-ously the conquest of Cisalpina Gaul.

The roman Senate required to Cenomani Gauls to expand the fortified castrum, which was on top of St. Peter's hill (Lessini Mountains), meanwhile they were busy with the foundation of a new city in the Adige bend. So far, it is ob-vious to see that, if you ask something to a population, it should mean that those ones were not at all subjected.

History, the true one, tells something else: in 390 BC there was a battle in Allia (this may have given its name to the Gauls), such battle was fought near the small left afflu-ent of the Tiber, and it was 11 miles far from Rome. In that area, 25-30 thousand men led by a chief (Brennus) de-feated Roman army, which was hastily formed after it was ordered a a military service (tumultus) (July 18th, 390 BC). Romans capitulated and Gauls were thus able to enter Rome without resistance and putting it on fire. The siege ended only after the commitment made by the Romans to deliver one thousand pounds of gold, but the intervention of Camillo persuaded Gauls to retreat, leaving much of the loot. It is clear that only an expert trading population could understand immediately how the sudden depletion of the other party couldn't provide any economic benefit in me-dium - long term and this, just this, might have been the reason for the speech of Camillus to his compatriots Velio-cassi so called "galli senoni". The well-known phrase [Non auro, sed ferro, recuperanda est patria] "not with gold but with iron you save your land! " made it possible to under-stand how the sale of large quantities of iron to the defeated Romans would bring lasting benefits to the community, who was settled at the confluence of Nera and Aniene. Af-ter this solution, Camillus, who was formerly part of ordo equester, was appointed commander of the Volscians, Aequi and Etruscans.

In $49 \mathrm{BC}$, Caesar declared that Roman citizenship was being granted in Verona and the rank of municipium and agro of 3,700 $\mathrm{km}^{2}$ was being given by the Lex Roscia.

At that time, tolls were widespread and transit was taxed in relation to the geographical location of the transporter: acquiring the Roman citizenship would have meant trans-porting and dealing in large part of Italy with a very 
low cost. Only in the capital, however, specific benefits were guaranteed for all dealers and thus, exempt from taxes and various tolls was assured. Everywhere, from Alps to Sicily, prices were different according to being or not being "Ro-man citizens".

When referring to Gaul, thus we have to refer to Galati, who was descendants of the Celts who invaded Macedo-nia, led by "second Brennus" [literally, the second king]. Brennus invaded Greece in $281 \mathrm{BC}$ and almost succeeded to reach the temple of Apollo at Delphi. Meanwhile, the Gauls killed the macedonian king Tolomeo Cerauno and afterwards they were rebuffed by Antigono Gonata, the grandson of Diodocus called Antigono I Monoftalmo. In 279 BC, other Gauls settled in Thrace and then, in 278 BC, they settled in Asia Minor. Nicomedes I of Bithynia had decided to seek help from the Gauls, in order to defeat his brother and therefore, three tribes (the Trocmi, the Tolisto-bogi e the Volci Tectosagi) moved far to Asia Minor. They were about 10,000 armed men, to whom we must add an equal number of women and children.

The new Celtic lineage colonists decided to settle perma-nently in the region (corresponding to the eastern Phrygia), which was known as "Galazia". Strabo described its state organization: according to the Celtic custom, each tribe was divided into "cantons" (as in Switzerland nowadays), and each one was governed by a chief (who was known as "tet-rarca", such term was often used in Palestine), whose pow-ers were almost unlimited, except for murder trials, during which the murderers were judged in a sacred place. Such place was known as Drynemeton (that is "temple of the oaks", those same oaks that have always been considered sacred in a vast area, from Asia Minor to the Brittany coast of France).

There was the custom to go into the oak forests in order to swear by touching the wood of trees (Indo-Iranic treu). Such operation had to be repeated seven times. From this ancient custom comes the word troménie (tro-minihi, in Breton language, it literally means path (tro) of the minihi (sacred space)) from which the Latin word: monachium (monastery) derives. The pilgrimage of purging is still well-known today in the pre-Easter Christian custom, which is called "round of the seven parishes". Thus we may designate as "ancient places to consider as sacred," even all Indo-European toponyms which have the following prefixes sett*, sezz* o $y^{*}{ }^{*}$ (in Azeri yeddi means "seven") and from which derives the etymology of Jeddah (in Arabic, Ciddə), sacred city for Islam.

If the original inhabitants of Phrygia had maintained po-litical control of cities and lands, they were actually re-quired to pay tithes to these "Galatians", who were sort of military aristocracy, living in fortified farms and separated by native (farms called "Qasim" from which then, "Cas-sim").

These Galatians, otherwise known as Gauls or Cassi, were valiant warriors and highly respected by both the Greeks and Romans. They had knowledge of the use of metals and used it to manufacture wheels and helmets. They often fought as mercenaries in the great battles of the time. For years, they had controlled the western part of Asia Minor and sometimes, they were allies of this or that sovereign.

\subsection{The Galatians in Northern Italy}

Regarding the land of northern Italy, historical informa-tions have always been very deliberately confused: histori-ans refer to the alleged culture of Golasecca and Villanovi-ana (proto-Etruscans) or to a vaguely defined "Bronze Age". For over a thousand years, until the advent of the Romans, trade and commerce, forge of helmets and gears took place on this country. Such business was spread all over an immense area, from the Atlantic to the Black Sea. A vase was found at Vix in Burgundy, finding dated 540 BC, and it shows the high quality achieved by Galatians crafts-men (Celts then). Furthermore, in this documentary evi-dence, wealthy life of this population is clear

Such Vix crater (named after the Latin because in French, this term indicates all vases of clear Greek manufacturing) is a proven fact.

In $540 \mathrm{BC}$, Carthaginians and Etruscans (united by com-mon origin and language) drove out the Greeks from Cor-sica, while Rome was still under the total influence of the Etruscans: despite what is repeatedly mentioned by some Roman historians, it is quite impossible that the first kings of Rome were only seven, considering the average age at that time and furthermore, the Urbe/City was ruled by various kings for about a quarter of a millennium (244 years).

Few real historical facts, as mentioned, but just about these ones it is necessary to proceed with the research.

In $171 \mathrm{BC}$, a vast land, that stretched from the south of France and Illyria, was run by Cassio Longino, ancestor of the most famous one called Gaio Cassio Longino, who over a century later, took part to the murder of Caesar, but rather than murder, it was - probably - just an action to restore democracy in the world and to strike to death those who had unjustly robbed and killed.

As Strabo asserts, Italy was inhabited by several tribes and they were united almost from a single ethnic group, since all of them were very little affected by administration and were devoted to a few and specific activities such as mining and metalworking, horse breeding, commerce. They were very cohesive and supportive to each other, shared a language (Semitic, considered of Phoenician strain). They were first ones to trace streets and to place milestones, fur-thermore they used to collect safe assets due to the tolls on transit. These early inhabitants, called by historians proto-Etruscans, took precautions - in a real self-defense system - in order that they could not be dispossessed by the Romans in any way, and thus, in order to protect those lands which belonged to them for generations, they had introduced ad hoc rules. Such rules were already included in drafting the "Law of the Twelve Tables" and as well, through them, for centuries, many taxes had not being paid, for example among them, those ones due to the norm of the right of burial. This perfectly explains the high number of busts and tombs 
along the Appian Way and other consular roads: from solemn tribute to the ancestors to a mere ploy to make an income for the coming centuries, and if necessary, trans-forming appropriate areas for graves in commerce place.

The skill in breeding horses, which is still alive today thousands years later, in some specific areas of Italy (Tus-cany, Cremona, etc..), such skill explains why there had always been a conspicuous presence of representatives of the ordo equester in the Roman Senate. Of course, each new war effort coming from Rome would push the gens Cassia (who provided both the means of transport - chariots and horses - and the manufacture of weapons) to significant and important assignments. Guaranteed revenues paid with public money. The name of Gallia Togata derives from the significant presence of many representatives of the ordo equester in the Senate. Such name was used by old historians to define the northern Italy, the Spain and a large part of the France. Strabo claimed (Book III, Iberia) that the tribunus militum (tribune of the soldiers) of the Roman emperor Tiberius owned the ordo equester. Tribunus ("epitropos" ع $\pi \imath \rho \rho \pi$ o $\varsigma$ in Strabo) was the procurator or laws protector name since the tribunus headed the ancient tribes. But what was the origin of such population so devoted to extraction of metals and breeding of race horses?

\subsection{The Kassites}

The Kassites (people able to work the bronze with appro-priate technology mainly as the ore cassiterite) were de-scents of Elam (offspring of Noah, Elam was the son of Sem and grandson of Cam and Iafet). Later on, they became known as Phoenicians (along the coast) and remained as Kassites or Cassi inland. They developed among the Ittiti, Hurriti, Kassiti, Hyksos and they were all experts in breeding horses, in the construction of wagons and use of metals.

They had knowledge of iron from $1600 \mathrm{BC}$ and such iron, at the time, was more expensive than gold (five times more expensive) and silver (forty times less valuable than iron). The Kassites used to live in a mountainous and inaccessible areas and they knew how to use stones as noboby else ever did (excluding the Etruscans, who came directly from them). They were powerful military architects, builders of strategically insurmountable fortifications. Their cities were a model of architectural perfection, that was able to fit to the characteristics of the ground and that used all the possibilities of defense

Sculptures and in general representations were of grand and solemn expression, either figures showing rulers or animals or other decorative items.

They used stones to mark the boundaries (these stones were called "kudurru") and over the centuries to come, the milestones derived from these ones, first Etruscan and then Roman.

The Kassites introduced taxes on transit and trade, in order to support expenses of worship (the Bible, the Book of
Nehemiah, V century BC).

There are many parallelisms between Hebrew and Greek and about the Elamites (also known as the Kassites and then gens Cassia), who were always busy with accounting, taxes, transportation. We find traces of that, even today, as follow:

- the letter $\varepsilon$ (epsilon lowercase) is used to indicate a small amount or a price (now defined exchange rate);

- the letter $\xi$ ("xi" lowercase) indicates a degree of ad-vancement.

- signing with an X meaning that a transported cargo "had been seen" (variations in the western Greek, when such letter $\mathrm{X}$ was used as/ ks /)

- the hebrew shekel (שקל), measure unit for carried weight, is identified with those same letters later to become Qoppa, Rho, Sigma and about that, we will find in all Kas-sites cities spread between Asia and Europe.

שקל (Shin Kof Lamed) when reading it backwards, as used in European languages, they are nothing more than $L K S$ (from which toponyms such like La Cassa in Torino, Cassano d'Adda, all the aLCaZar, because aLCàSser in Catalan etc.). Furthermore, the word ק (sk) means "bag" or "pocket" and - always read backwards - $K S$, in hebrew, like the preceding lemma with reversed letters שק (kash included in the lemma of the shekel שקל), indicates either "straw" or "straw basket" or "rush". First traders in the ancient world were Kassites, they had introduced weights and measures, payment systems, precise mode of transport and they spoke Hebrew and moved in a very large area, from the Atlantic to Asia far to the south of Egypt. This term $K S$ turned into Cassia in European countries and, in the Semitic-speaking countries, into Qeshm (island in the Strait of Hormuz in the Persian Gulf, commercially very prosperous until 211 BC) or into $Q s$. Such term is still pres-ent in all languages of the world and it indicates fundamen-tal vegetable substances from the medical and practical point of view, both for food consumption or for other uses.

We see them:

Cinnamonum Cassia. The cinnamon powder [القرفــــة which in Arabic is pronounced canela] was used for arthritis: small incisions in the body were practiced where the pain was stronger and these signs can also be found in the Similaun Man also called Ötzi the Iceman (spine, left knee and right ankle). The spice trade and the commercial network, in ancient time, stretched over vast areas (thousands of kilometers) and it is not a coincidence when in the Gulf of Aden, we find the city of Bossaso, formerly called Bender Cassim (or Bandar Qasim), which was already known to ancient Greek traders, those who made the circumnavigation of Erythraean Sea. Here caravans arrived from all over the Horn of Africa, as well as ships from India and China. Similarly we have Qaem Shahr, south of the Caspian Sea.

Cassia Syrinx. Multiple uses of Cassia Syrinx, a name that refers in general to cinnamon (cinnamon, able to reduce risk factors associated with diabetes and cardiovascular diseases), and also etymology in various languages, from Hebrew to 
Greek, to refer to both connection systems (ducts, pipes) and a system that innervates the body, in the medical field: from

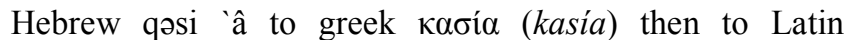
$\operatorname{cassia}(m)$.

Cinnamon has a long history: it was already mentioned in the Bible, in the Book of Exodus, it was used by ancient Egyptians for embalming and also mentioned in the greek and latin world. It was used for centuries both for cooking and for medicinal uses. Some people widely used it for embalming. As a matter of fact, this spice has an antioxidant activity among the highest ever, it contains tannins, cinnamic aldehyde in the essential oil, eugenol and over 50 aromatic compounds and camphor. It was used against colds and as antibacterial and antispasmodic, and today is also appreciated for its ability to lower cholesterol and triglycerides in the blood, helping to alleviate problems of hypertension. Ayurvedic and Chinese medicine used Cinnamomum cassia for the treatment of fevers, for some intestinal disorders and for problems related to the cold, as it has a heating effect on the body. The essential oil of cinnamon facilitates bloodstream and if it is rubbed on the skin, it might help for fungal infections.

Herodotus asserts that the use of Cinnamomum cassia was introduced in Greece by the Phoenicians and it was not produced in that area but was marketed since antiquity. Even the Bible mentions the use of cinnamon for the warming effect (in the biblical metaphor, the meaning was of giving heat to the Soul).

Coussade (pond grass, since the Equisetum arvense - field horsetail or common horsetail - grows near all the wet places and it is extremely popular in the entire Alpine range) is a plant similar to a phallus and from which come the italic term "cazzo" (cock). It contains: Silicic acid (up to 15\%), glycosides of saponins (equisetonina), flavonoids, small quantities of alkaloids, resins, organic acids but also contains vitamin $\mathrm{C}$, along with some bitter substances and other minerals (potassium, aluminum and manganese). It has multiple curative properties: anti-hemorrhagic, remedial (accelerates the healing of wounds), hemostatic (blocks the leakage of blood in case of hemorrhage), diuretic (facilitates the release of urine), astringent (limits the secretion of liquids), anti-tuberculosis and remineralizing (especially worth for patients with pulmonary tuberculosis) and anti-arthritic. The Equisetum arvense was added to soups or stews as a good supplement of mineral salts. The silicic acid, which is present in coussade, was exploited to rub all metal objects using stems of Equisetum arvense, in order to obtain the perfect polish. Such operation was easy because of the shape and the elasticity of the stems themselves so they were often used for the cleaning of internal parts (in recent centuries, it has been used for the inner cleaning of musical instruments).

The Equisetum arvense was also a yellow dyed for fabrics and it was the color - along with the purple - with which the Galatians, then called Gauls, dressed - as is attested by the etymology gelb (yellow in German, galbus in Latin and galbinus in Martial).
When the latin writers mention that there were always "asparagus" on Roman ships it is may be possible that, they had been referring precisely to the shipped equisetum, in order to avoid deficiency diseases of vitamin C. Even because the etymology of the word "asparagus" just denotes a plant growing only "in a place which is characterized by roughness", precisely as a watercourse. A bundle of Equisetum arvense was confusing by historians into a bundle of birch rods. The fasces symbolize the executive power and strength (of the tribes) through unity. The reed plant were used to cover the roofs and in Arabic, the word qasabah means both "fortres" and "reed". This material was used once for its ergonomic and economic properties in the construction of roofs as insulation thermal (against heat, cold and moisture or humid conditions). In Kasba (Bihar, India) the entire area was covered with the long green grass called Kashal (mainly used to make huts), and it is believed that the name of the village Kasab derives from that word: it was an important town for the production of rice, jute and cast iron goods.

Cassia Sena or Cassia Obovata used for therapeutic properties and to lighten hair and make blond.

Cassia Aethiopica is used for medicinal purposes too.

Cassie (in French) is also a variety of mimosa, which is still growing in Provence and is much used in perfumery for its yellow flowers,.

Khash, a nutritious winter food, is a traditional dish in Afghanistan, Armenia, Azerbaijan, Iran, Iraq, Georgia, Bulgaria and Turkey. A variation of that is found in other Arab countries such as in Egypt and is known as Kawari' and Kissra in Sudan. The dish is known in Kuwait, Bahrain and other Persian Gulf countries (where the temperature is higher) as Pacha (ياجَ) too and for this reason, in Europe, we say "live like a Pasha". The correlation with the ordo equester is clear because there were three ranks of pashas: the first, or highest class, had the privilege of bearing a standard of three horse-tails, the second of two, and the third of one. Only the Sultan himself was entitled to four tails, as sovereign commander in chief.

Cassava similar in French (cassave), in Spanish (casabe), Portuguese (cassave), and Haiti (caçabi, earlier in English as cazabbi) also called manioc, used as food in tropical America.

There are many parallelisms between Hebrew and Greek and about the Elamites (also known as the Kassites and then gens Cassia), who were always busy with accounting, taxes, transportation. First, they had introduced weights and measures, payment systems, mode of transport, agricultural, farming and fabric techniques, and they spoke Hebrew and moved in a very large area, from the Atlantic (and had contacts with Koishan language populations) to Asia far to the south of Egypt.

But even in the English language there is evidence:

Cashroom, gaelic Cas (foot) with room/chrom instrument of tillage called also foot plough;

Cash, a box for money, it used in these contexts was derive from the Tamil $k \bar{a} s u$, a South Indian monetary unit, 
Sanskrit karsha, Sinhalese kasi;

Casket and chest: small box for jewels

Caseation: coagulation of milk;

Caseharden: to harden on the surface;

Cassie (or casie, caisy, caysie, cazzie, caiss): a basket, like a pannier, made of straw, or dried reeds and it's used to carry food.

In Old English, caserm: one of a series of small temporary building for soldiers;

Antique Irish cashmel is a circular wall enclosing a group of churches and their appartenence;

Cassock (French casaque, Italian casacca, Spanish casaca) a long coat worn by soldiers and knights.

Cashmere, whoolen fabric;

Casbah, North African Arabic dialect kasba o qasaba means "fortress." Ksar or Ksour (Maghrebi Arabic: قصـر qser, plural qsur for a network of fortified villages);

Cast-off, abandoned;

Cast-iron, an alloy of iron and carbon, also used in the construction of buildings. Cast, metallurgy three-dimensional form and a manufacturing process using a fluid medium in a mould, so as to produce a casting;

Castellated, in defensive architecture, "furnished with turrets and battlements";

Cast, launch the process whereby a anchor, a bait or lure is placed into or onto the water;

Caster, a thrower who rectifies the rivers who use the foot plough (cashroom)

Castrametation, the art or science of laying out an encampment;

Kiosk, open pavillon, Turkish koshk "pavillion, palace".

Kiss, to put, bring, take or to touch gently or lightly still present in the expression "kiss and make up" words based on the $K^{*} S$ which then find in "Kama Sutra" which means the role (sutra) of love

Kiss, to put, bring, take or to touch gently or lightly still present in the term "kiss and make up" words based on the $K^{*} S$ which then find in "Kama Sutra" which means the role (sutra) of love. Correspondences that we also find in the word cashew, "anacardo" in Italian "similar to the heart"

Squad, a small military unit (contubernium it was the smallest military unit in the Roman legion and soldiers group shared a tent);

Squat, hidden from observation;

Scearp (Old English) cutting, keen, sharp;

Scatter, disperse, disseminate;

Scarry, precipitous, rocky;

Scarp, an escarpment, steep embankment, (Old English) fortification;

Scaffold, wooden framework;

Scarlet, red toga, rich cloth often bright red in color; there were three different kinds of toga trabea: one purple, only for the Gods; another crimson and a little bit white, for kings; and a third kind, with scarlet stripes and a purple hem, for augurs and equestrian class. The toga trabea, as shown in its etymology (trabs), was decorated with bands in relation to the various tribes of belonging. It's interesting to note that Sextus Pompeius Festus [16], attributes the etymology of the term "Trabs proprie dicitur duo ligna compacta" (this refers to pieces of wood joined together).

Scavage, a tool formerly levied on merchant strangers by the mayors, sheriff, corporations of various towns, on good offered for sale;

Scavenger, an officer whose duty it way to take scavage and later to keep the street clean;

Scatter, to separate and drive off in various directions

Score, a notch, scratch, or incision

Scot, a payement, local contribution

Scallop, shell

Peace in the Mediterranean Sea (a commercial peace if you want), ended just when the Romans started to invade nearby areas. Thus, they conquered Illyria (in $228 \mathrm{BC}$ ) and just afterwards, the North African coast (with the foundation of new carthage). The word "pax romana", then must have sounded like a mockery for all those people who had been living more or less peacefully for over a millennium.

\section{People and Toponyms}

History of cartography is identifie with the history of men who have always tried to satisfy two of their basic needs: the safety of the place of residence and the desire to move and to get food and resources. Consequently the map has always been a key tool in its broadest sense and, therefore, some elements might have been purposely obscured. Strabo claimed that "description of the countries" had to respond to specific policy needs, to be intended in its full broadest sense: economic, military and strategic matters. No surprise therefore, whether with regard to our Peninsula many historical in-formation have been in time purposely obscured. Elamite people. otherwise called Kassites, have always continued to migrate - even because they enjoyed livelihoods significantly higher than those of contemporary ones - and when population threshold was overcome and deemed optimal by each settlement, small groups had been leaving in order to colonize / found a new settlement. Always Strabo exactly mentions how this could happen: " If the harvest had not been enough, they used to declare that all the young, born that year, had to be devoted to Ares. Therefore once achieved adulthood, those ones used to move and go to colonize new lands". Thus from Asia Minor, such process had gradually localities affected even thousands of kilometers far away and had helped to populate a large part of Europe.

The Kassites, mindful of the Flood, preferred locations with precise and recurrent characteristics: they had to be situated on the heights, near the confluence of the rivers, seashore or near the lakes. Overall, they were peaceful and busy in trading tools that they forged and fabricated, furthermore they were totally uninterested in creating a unitary state but however, ready to help other popolation when they called them. We have evidence of it, also in the 
also in the Commentarii de Bello Gallico [13]. Such text, sorry to point out - from the 1575 dated version of Aldus Manutius, has undoubtedly led to "construct accurately" a "Roman" history, which otherwise would have remained unknown.

We have evidence of it, also in the Commentarii de Bello Gallico [13]. Such text, - sorry to point out - from the 1575 dated version of Aldus Manutius, has undoubtedly led to "construct accurately" a "Roman" history, which otherwise would have remained unknown. Personally, I think that book was written by Strabo in Greek (and was part of lost History books) and then translated into Latin. Strabo was Caesar Gnaeus Pompeius Magnus son. For example the description used to report distances at the end of paragraphs is the same adopted in his Geographica books.

In several passages of De Bello Gallico we have evidence that the Galatians/Gauls that Caesar was fighting were not a barbarous people:

a) "There were in all two routes, that they could follow to leave their country: one through the Sequani narrow and difficult, between Mount Jura and the river Rhone (by where only one wagon at a time could be led; there was, moreover, a very high mountain overhanging, so that few might easily intercept them; the other, through our Province, much easier and freer from obstacles, because the Rhone flows between the boundaries of the Helvetii and those of the Allobroges, who had lately been subdued, and is in some places crossed by a ford. The furthest town of the Allobroges, and the nearest to the territories of the Helvetii, is Geneva. From this town a bridge extends to the Helvetii. They thought that they should either persuade the Allobroges, because they did not seem as yet well-affected toward the Roman people, or compel them by force to allow them to pass through their territories." $[13, \mathrm{I}, 6]$

b) Dumnorix for a great many years has been in the habit of contracting for the customs and all the other taxes of the Aedui at a small cost, because when he bids, no one dares to bid against him. [13, I, 18]

c) Were brought to Caesar some lists found in the camp of the Helvetii, lists written in Greek characters, where there was an estimate of the number, name by name, of the number which had gone forth from their country of those who were able to bear arms; and likewise the boys, the old men, and the women, separately. [13, I, 29]

d) After delivering this speech, Caesar dismissed the assembly; and, besides those statements, many circumstances induced him to think that this affair ought to be considered and taken up by him; especially as he saw that the Aedui, named repeatedly by the Senate "brethren" and "kinsmen,"... [13 De Bello Gallico, I, 33]

e) And if the most ancient period was to be regarded-then was the sovereignty of the Roman people in Gaul most just: if the decree of the Senate was to be observed, then ought Gaul to be free, which they [the Romans] had conquered in war, and had permitted to enjoy its own laws." [13, I, 45]

f) Their ships were built and equipped this way. ...The ships were built wholly of oak, and designed to endure any force and violence whatever; the benches which were made of planks a foot in breadth, were fastened by iron spikes of the thickness of a man's thumb; the anchors were secured fast by iron chains instead of cables, and for sails they used skins and thin dressed leather. [13, III, 13]

g) But the barbarians, upon perceiving the design of the Romans, sent forward their cavalry and charioteers, a class of warriors of whom it is their practice to make great use in their battles, and following with the rest of their forces, endeavored to prevent our men landing. [13, IV, 24]

As we know, the Kassites had knowledge of the use of metals, they were skilled tradesmen, bred horses and used them for carriage, and furthermore, they invented and used wagons and introduced tolls. This population, forced into a sort of climate diaspora caused by the outbreak of the Biblical flood, expressed originally in Hebrew (1700 BC) and then in Phoenician, Punic and those languages that we today call Etruscan or Celtic: Hebrew is still used in scientific publications for the transcription of Phoenician and Punic epigraphic texts. Based on this assumption, some recurring toponyms were then analyzed and etymology of words that referred undoubtedly to the Kassites, then known as the Cassia gens. Toponyms that refer to the $L K S$ letters and also to the $Q, X$ and $G$, as many transliterations have occurred in Indo-European languages, over the centuries.

A fascinating research path, starting from Cassano d'Adda and crossing time in a couple of millennia, such path closely involves even those in charge of transport topics, since in French the word "cassis" refers to such paved grid or such drainage slops along a road, so far, open air vents used to convey water to the roads sides, covered with stone and later with metal, also placed in the center of major junctions.

\subsection{Recurrent Toponyms}

In Cassano d'Adda area (in the center of the Po Plain), waterways (toponyms coming from IGM cartography) are called roga (Roggia Rivoltana, Roggia Moia Lunga, Roggia Cremasca, Roggia Firone, Roggia di Mezzo, Roggia Brambilla, Roggia della Fontana, all of them abbreviated as Rog.a and then Rio Rampazzone) and there is also a Cascina Dazio near Arcene (formerly toponyms of Cascina Arcene) just east of the Adda, while in the center of Cassano, we see such toponyms as Cascine Alte and La Volta (as well as Camerata Cormello, since Camerata in Latin means "vaulted building" and one of the key advantages of the vaulted building is that it can be built without any support or shuttering).

$\mathrm{Ro} / \mathrm{ru}$ to point out water and waterways (and Rumon was the name of the Tiber/Tevere), Rhine and Rhone. This in turn derives from Indo-European $* R u g$, from the root $* r u$ - "to makes noise", which is also the root of words like rumor, ruin and run.

In an area of continuous passage and transit, names tend to be assimilated and that's why we find, in the south of France, toponyms and etymologies that can be understood as the similarity because of the evidence with the Italic dialect 
(from north to south): it turns out, in fact, that éboulis means "gravel" and so there's no wonder to find an Italic Eboli and some "gera" [gravel] near Cassano (Fara Gera d'Adda) referring to the same meaning. When water passes over the gravel, it slows down and makes noise, therefore we have, cassure, that in French means "pause" and jacassent that means "chatter".

Aboucassi means a land which has become wild and covered with shrubs, as if the land had previously been leveled by the Kassites. In Languedoc, the containment wall of a stream is called, rascasso, and in Corsica, scassa means to level the ground, while scassata means glade in forest. In the old French, cassis meant bridge. Cassis was the side of a street gutter, often made of stone embankment or other material. Cassis was always called the cross slope to provide a drainage gradient so that water will run off the surface to a drainage system such as a street gutter or ditch. Cassis was also the grid for inspection of open sewer. It means that the Kassites built just a lot of roads.

In Gascony, it said casadeban to mean "house in front" and casadarrè to mean "house on the back" that's very similar to the Lombard dialect. Casal has the same meaning as in Piedmont and Lombardy (casal, meaning house and nearby possessions). In Gascony language, casal, was also an ancient measure unit of the land, and casala also means fence (it is also written as cazalas, with $\mathrm{z}$ indicating a double $\mathrm{s}$, then cassala means enclosure) and so even in Corsica. In the area of Briançon, cassa remains with the meaning of isolated house.

Briançon (1,326 meters above sea level, is the highest town in France) takes its name from the ancient Gaulish (still existing in the ancient Irish) Bri means top, summit, and since those who dwelt in high places as well gave name to their towns, we find such toponym as Brixia, today called Brescia (see also vases of Vicarello and Gaditanum itenerarium ).

Recurrent and similar toponyms, in the form $b^{*} r^{*}$, are present in far away Countries such as Buraidah (Al-Qassim province in Saudi Arabia), in England Berkshire or Bearroc (Vale of White Horse, bordered to the north by the ancient boundary of the River Thames). And in these high places breeding horses, forge iron (for tools and weapons) and eat of it as evidenced by the Greek words related to these activities ( $\beta \rho$ ó $\mu$ os [bromos] rattle, shudder, $\beta \rho o v \tau o v$ [bronton] thunderer, $\beta \rho о \tau$ ó $\varsigma$ [brotos] mortal, $\beta \rho о \mu \alpha$, [broma] food, edible $\beta \rho \omega ́ \sigma \mu \rho \varsigma$ [brosimos], $\beta \rho o \sigma 1 \varsigma$ [brosis]. In Southeast Asia toponym is Burma or Barma.

As we can see, from Cassano d'Adda (Milan) to Brescia, the linguistic step is very short and history shows a clear path yet to be revealed.

For centuries, Transpadana Gaul has designated all existing regions of the Alps range, and that so called area was extended from Provence to Friuli Venezia Giulia and habits and customs were all over the same as well as the language. Thus the word cassoula in Piedmont and in French language is referred to a plate, it means a grove of oaks, as well as bouscassé means those who live in the woods but also those who cut down trees in order to live there; the word bricassalho means those who make stone into pieces. Such ancient people, who gave names to these places, had the characteristics that we have already mentioned: they worked metals and therefore it was essential to break stones. In order to find metals they built roads that climbed mountains, and so today, in the French dialect, casse-cou means "daredevil" (who is not afraid of danger), such term is costo-cato in Provencal language and it means - as well as daredevil - even narrow and steep road. Those, who used to work metal breaking stones, built as well roads and as long as roads network (the Latin word, network, is cassis) gradually thickened, toll stations were built and over there (because of settlements presence), it was possible to trade, rest and have a bite: thus (always in French dialect), there is the term cassotalen which means break-hunger (a term still used in the Gers and in the French Pyrenees) and also the word, cassine, which means small house, recurs throughout central France.

In French dialect, casse / cassano means a place where there are oaks, and as already explained, oaks were sacred trees.

\section{Gens Cassia Or Rather Gallia Togata}

So could the origins of Cassano d'Adda be Celtic? Sure, but just as here explained: Cassita people, then called Gauls and then renamed as the gens Cassia.

It's interesting to note that Strabo highlights how the toll was imposed by the Massalioti, which are installed along the Rhone, even for goods that are transported along the rivers or canals.

Olinto Marinelli [15] wrote about such town, whose etymology is very close to Cassano: "In the case of Montecassiano... etc. villages arose for reasons of defense on top of hills surrounded by escarpments. The map "always shows the tops on which they were built»". Settlements developed downstream along the main roads of communication. The original urban settlements, which developed along the hilltops for defensive purposes, were often of pre-Roman age." Such history was certainly less warlike and more important for the final structuring of the land.

Although over the centuries, there have been many new names and many others have been cancelled leading to the gradual disappearance of some toponyms, it is possible to go along with the paths of the past and draw an economy and administrative geography that had nothing to do with Rome. Even today, two thousand years later, people, who are settled in such so called "places of the Celts", aim to emphasize the distance from the policy of the Urbe/City.

Whether everyone is aware of the fact that the oak had magical power, according to the Celts, not everybody knows that the oak is symbol of a Israel house. In ancient times, the oak branch was a symbol of virtue, strength, courage, 
dignity and perseverance and in military field, oaks had always been the symbol of virility and value. It was not a Roman symbol, but later it became so. The oak had been venerated by the house of Jacob and it is several times mentioned in the Bible. So far, Jacob, father of Joseph, who was appointed as minister of Pharaoh, has always boasted important roots in Egypt.

Such relationships counted so much, even in later centuries, when, in the second century AD, the Cassii were still related with Antiochus IV of Commagene, who was immensely rich, and in close contact with largely Jewish aristocracy. Historical analysis, concerning Gaius Avidius Cassius, refers to him both with the name of Alexandria, on the maternal side, and the name of Cassio Agrippa, which was a common name among those reigning in Judea. Gaius Avidius Cassius was the son of a egyptian prefect of and belonged to the ordo equester, which members of the Senate, who were in charge of roads and connections: he had a rapid career and he got first a Praetorian position and then a Legate one of the Legione Italica (year $159 \mathrm{AD}$, at the time of Antoninus Pius) and then of the Gallica (162). In 164 A.D., when he destroyed Seleucia on the Tigris, he was appointed Legate of the Cyrenaic Legion (166) up to achieve the title of Imperius Maius of Orient (169 - 175, time of Marcus Aurelius). History of symbols and toponyms helps us to connect the ancient city of Alessandria of Egypt to Alessandria at the confluence of rivers Tanaro and Bormida. Such italic capital, in Middle Ages, was still known as Alessandria della Paglia (and as we know, Paglia (Straw) in Hebrew is שק (kash).

Transit points for goods all the toponyms in the form $q * s^{*}$ or $k^{*} s^{*}$ as Qeshm and Kish islands, in the Persian Gulf or the old Kish near Baghdad. The Khazars (in hebrew כוזרים in

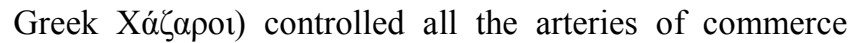
between the northern Europe and the southwestern Asia and played a key commercial role as a crossroad between China, the Middle East, and Europe and the greek word $\chi \alpha ́ \zeta \omega$ means "remove" or "separate" because the goods were taxed.

Ordo equester had been known since the founding of Rome in $753 \mathrm{BC}$, and those families, whose members were in the equestrian order, had an indisputable political power: many of them covered sacred positions (ordo decurionum) despite, however, also belonging to the ordo equester. Many of them were merchants or manufacturers / entrepreneurs.

Historians have handed down the importance of this order as that to be defined as the first trial of extortion. At that time, the ordo equester established both tolls and routes for cargo to be transported, and from payment of these tolls, the Senate had excluded those who could boast of Roman citizenship. Some people - including those who had a view to secure gains and had helped to build these roads - dared to oppose this law, since it was meant to be a sure loss of income from transits, so in 122 BC Caio Gracco introduced the Lex Sempronia Iudiciaria, in order to settle the issue (for and against such tolls), that later will be defined as "partisan court": such issue did not go well (for the Gracchi family) and although, at first, they got to be able to acquire some free lands in Carthage area, they were soon killed. The wealthy Roman senators, who had cheaply acquired lands around Mediterranean Sea, were no longer willing to pay high taxes to transport and sell goods to any gens Cassia and here, around the second century $\mathrm{BC}$, a slow battle began and lasted for many centuries. It's not possible to maintain an empire, if streets are not kept well and countries are not well managed by a dense network of valid and competent representatives. All agreements and contacts arranged by the Cassii in order to weave cleverly, through the centuries, al of that finished. It was the end of Rome.

\subsection{Symbols and Places of Origin}

First inhabitants of Rome were divided into several tribes (Gaul) and converged on what would be later called as Campus Martius for certain ceremonies or rituals and to discuss and elect leaders. It was forbidden to address issues of common interest other than in public meetings. These places were called "septae" and still today, it is said to be "divided into seven". Architectural items remain: elliptical corrals where they could vote and pray to the ancestors as tutelary deities. This was a common practice throughout Italy, and we find these same toponyms in many Italian regions (toponyms beginning with $\operatorname{sett}^{*}, \operatorname{sezz}^{*}, \operatorname{sep}^{*}, \operatorname{ses}^{*}$, $\left.s i t^{*}, s i s^{*}, \operatorname{sed}^{*}, \operatorname{sal}^{*}, \operatorname{sap}^{*}, \operatorname{seq}^{*}, \operatorname{sib}^{*}, e q u^{*}, a c q^{*}, c a v^{*}, \mathrm{bri}^{*}\right)$ because in all these places, public meetings were held and equitable judgements were taken on those who had done wrong. Near a toponym $b r^{*}$ there's always one of these toponyms $s e q^{*}, s e p^{*}$, etc. for the plublic meetings: e.g. in France Séqué near Biarritz ancient Bearriz. And near Brescia was the ancient Salona (now Salò).

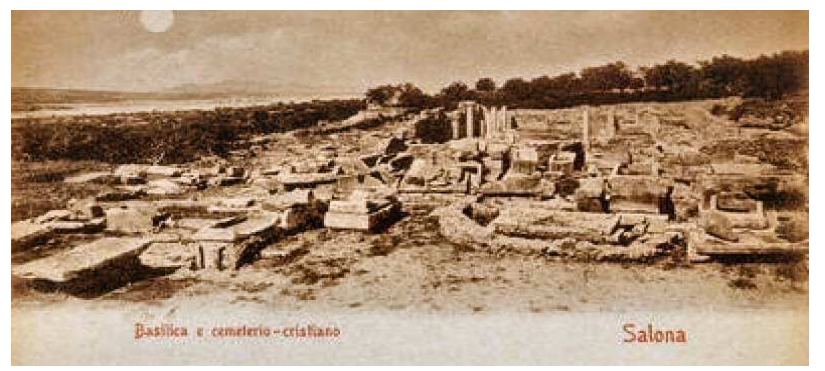

Figure 1. Salona, Garda lake

It's interesting to note that Sextus Pompeius Festus, in the second century $\mathrm{BC}$, attributes the etymology of the term "faction" to the disputes, which took place between "those who spoke in public" and "those who drove carts."

Kassites, descendants of Jacob, had a Menorah as a symbol, it was a seven-branched candelabrum, as well as the number seven represented the pre-Vedic deity Agni, who argues in adversity, thanks to the forces of light (a metaphor for the Souls that help the living). If Agni is always represented riding a ram, for the Kassites, one of the other symbols, as well as the number seven, was the horse. Horses and carts allowed the Cassii (Veliocassii as Commentarii calls them) to get anywhere in the world.

Strabo - a contemporary of Caesar - also treats the issue of 
symbols concerning ordo equester [then gens Cassia]: in Rome there were many statues of horses and many symbols of horses are as well present in the Italic country (and often even in churches and basilicas). All that was played on names, symbols, and still today we use to say judgment to be "equo" meaning in italian to be "fair, equitabable". Furthermore, when mentioning what was then called ordo equester, we will also need to see those who gave name to this order and passed over the centuries the concept of "knight", as a noble person acting on a straight line due.

History mentions the Aequi, for the first time, when they were engaged in battle of Mons Algidus, in $431 \mathrm{BC}$, it was a dispute of Romans against a coalition of Volsci and Aequi, and ended in a truce with those last ones. Aequi and Volsci were clearly superior in terms of war, and thus it is told, they were a serious threat for Rome, forcing the Urbe/City to appoint a dictator, Aulus Postumius to organize a counter-offensive. Always at Mons Algidus, some decades earlier (458 BC), the Romans had temporarily rejected an advance of the Aequi, led by Cincinnatus. It is said that one of the two Roman consuls, Minucius, was surrounded by superior forces, and that it became necessary to appoint a dictator in the person of L. Quinctius Cincinnatus, who was a modest and honest patrician, former consul in $460 \mathrm{BC}$. According to tradition, Cincinnatus received news of his nomination as dictator while he was working on his fields and after he bargained for a truce with the Aequi, he refused honors and rewards and put the command in order to return to his farm. More than a valid commander, Cincinnatus seemed to be a fine diplomat.

In the country of the Aequi, among the cities, Alba Fucens was one of the few settlements for which we have evidence of a paved road segment, which was arranged for the wagons slowdown.

The Aequi people, who were called in later times as the Insubri people, over the centuries, however, already long before Rome was founded, had extended in Enotria, later on called as Italy, and also largely populated the area of Po Plain, which was called as Gallia Insubria, as mentioned in the texts. The names were changing, and then other authors have declared that Padania was called Traspadana Gaul (area from the river Po to the Alps) and Cisalpina Gaul (areas on the south of the Po). If the name was "still" Gaul, in 18 BC, when Strabone wrote Geography, it means that this area was entirely inhabited by peaceful Gauls: peaceful but forced to arm themselves when Caesar decided (in 49 BC) to cross the Rubicon with clearly warlike intentions. The history is known, the civil war between Pompey (who took the side of the Gauls) and Caesar. Cato Uticensis, accused Pompey of private interest concerning country settlement, nomination of its customers in key posts in the provinces of Asia and maintaince on the borders, of kings and rulers, who most likely had shelled out huge sums to be kept or placed on throne. Cato Uticensis was already deployed when, years before, he was opposed to Marcus Licinius Crassus, who had requested a partial refund to the equestrian order of the huge sums already paid and forfeited by the Roman Senate. Such amounts were related to tax collection in Eastern Provinces. Cato had ruled that negotiations were regularly carried out as contracts which were read, accepted and signed by the concerned parties and that ordo equester should have been content to earn a little less.

Historical twists and claims, we might say: there are no real political objectives in history but only economic interests - if necessary - to unfold in politics.

\subsection{The country of Aequi}

The Aequi were an ancient population that occupied the area, today known between Lazio and Abruzzo, constantly mentioned in Livio's first decade as hostile to Rome, in the first three centuries after its founding in $753 \mathrm{BC}$. The Aequi, as well as all the Gallic tribes which derived from the ancient Kassites, had built their cities near the water sources of Aniene (tributary of the Tiber, which was once called Rumon), and of other rivers called Turano, Imele and Salto, all tributaries of Nera (water course which - in spite of its limited length - has a fundamental importance in the hydraulic system of Rome, because it accounts for $2 / 3$ the annual average flow of the Tiber) and thus a possible uptake of water by the Urbe/City was virtually impossible without the consent of the Aequi, and so far, it was not possible, at least, until the second half of the second century BC.

We should therefore never supinely believe the stories as they have been so far reported but we should instead see other details: Veliocassi were called as Oueneliokasioi in Greek language, which has a strong phonetic similarity between Ouen and Aniene. The name of the Tiber was Rumon and Strabone also mentions how, in almost all of Italy, those ancient people, who founded the first cities, in the same way, called the river and the city. A custom that survives even today from north to south: for example the many toponyms such as Cassarate, in Lugano, Switzerland, are used to indicate both fractions and the tributary river of Lago Ceresio.

\section{Tolls, Roads and Toponyms}

The Kassites, Oueneliokasioi, Veliocassi and then gens Cassia were known for transport, trade and for the ability to work metals. If the average flow of the Nera is comparable to that of the Arno (which, however, suffers from heavy seasonal variations in flow rate), the regime of the Nera is among the most regular in the hierarchy of the Italian rivers. This abundance of water allowed the creation of one of the largest hydroelectric systems in Italy, between the Nera and its major tributary called Velino. These populations, which then formed the gens Cassia, were allocated a bit all over the Italian country and showed some common characteristics: they were not at all warlike and were so reliable that Strabone mentions how those, who were defined Picentes or Picentines, " instead of military service, they were massively appointed to public assignment in order to be couriers and 
carry letters, as it happened for Lucani and Bruttii for the same reasons"

A tax existed in all forms of trading, throughout the entire Empire. Entries usually show the toll for the transit with the formula: «..., prefect of..., he had engraved in this stone with the sums that have to be exact ... as a toll.». At the archaeological museum of Vicenza many milestones are there to attest this.

Crossing point even in Roman times and, therefore, it was such very important point concerning the control of country and trade. The more a place is strategic, especially over the centuries, the more is subject to many vicissitudes of war. This was the story of Cassano and many other places in the world that belonged to the gens Cassia.

\subsection{Toponyms in the Gaul Traspadana Map}

A network of Roman roads existed and used to connect Bergamo and Piacenza, Varese and Brescia (roads controlled by the family of Cassii, as attested by the several toponyms attributed to the gens Cassia along these important roads).

If you look at the maps of Abraham Ortelius, at the center of the Po Plain, right in the land crossed by BREBEMI (Brescia-Milano highway), you can see an unique toponym: "Castorum lucus " mentioned by Tacitus and Orone as "Castoris Locus".

This locus Castorum, mistakenly referred to as Pizzighettone, was in reality the vast land guarded by gens Cassia and between the Adda and the Oglio, with explicit reference to the two Dioscuri, Castor and Pollux - always represented with a horse and even on the back of coins (quinarius) which were spread in the second century BC: gens Cassia had as symbol Castor and Pollux with their two horses: Dioscuri [name indicating two Kouroi or two male statues without clothes (from singular Kuros, standing male statue)] the two "kouroi" were always represented with a small metal helmet (cask, in Latin cassis) while with one hand holding a spear and the other one holding the reins. Even the two very famous Riace bronzes were two "kouroi".

The gens Cassia had many statues of the Dioscuri in their countries and there are copies still in Rome today, in the Capitoline and Quirinal Hill.

A story that is summarized in statuary but similar in potteries or in a contemporary crater, now in the Louvre where we see Castor with helmet and horse, and by side, the Etruscan wheel is represented, also in St. Peter's (Montelupo Fiorentino, at confluence Arno and Pesa river). Remaining examples of columns engraved with horses are in the cathedral of Lodi. Symbols which, in more territories to the North, will change a little bit: a God with the wheel that rolls, as in the Jupiter Column (Jupitergigantensaule). The pillars depict the victory of Jupiter Optimus Maximus over the forces of Chaos, the god himself being raised high above the other gods and humankind, but closely linked with them.

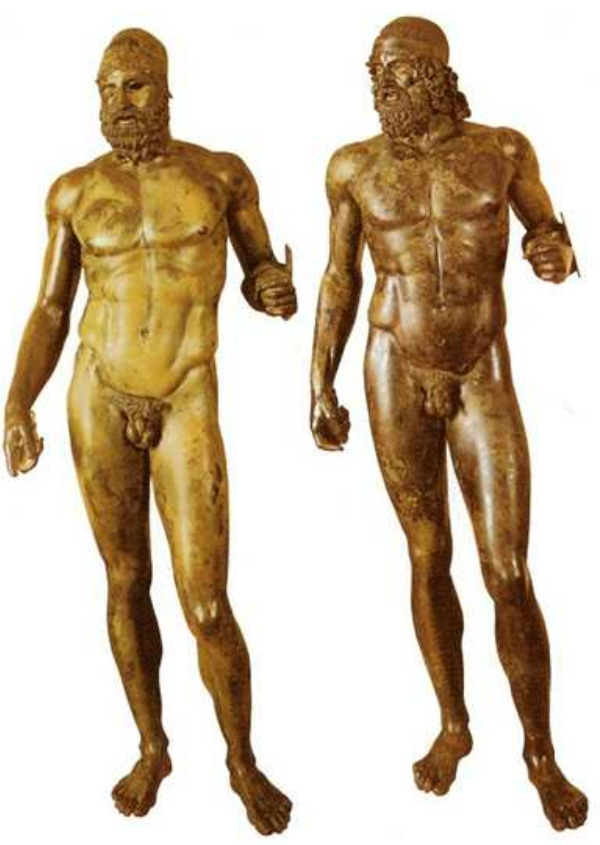

Figure 2. Riace bronzes

\subsection{Toponyms of the Gens Cassia}

By analyzing the toponyms in northern regions and in neighboring Switzerland, we can set up a meaningful picture and perhaps that is not yet fully explored, toponyms beginning with cass ${ }^{*}$, cast $^{*}$, bri $^{*}$, gard $^{*}$, sett $^{*}$, sezz $^{*}$, sep $^{*}$, $\operatorname{ses}^{*}$, sit $^{*}, \mathrm{sis}^{*}, \mathrm{sed}^{*}, \mathrm{sap}^{*}, \mathrm{seq}^{*}, \mathrm{sib}^{*}, \mathrm{equ} \mathrm{u}^{*}, a c q^{*}, c a v^{*}$ and also all the toponyms prefixed with Gard (Gardone Val Trompia, Gardone Riviera) since the toponym Garda is the evolution of the Lombard term warda, or guard, which means a high place, suitable for military lookout or fortified barrier. And in spanish "garganta" is a pass (for controls) between mountains and "garamantes" in Arabic language. Name that we find thousands of miles away in Qatar (Gwada) or Pakistan (Gwādar and Al Khawr) or India (Gwalior), all strategic locations. Persian گ گ (gad) is "travel around" and in Urdu is "protected place": from here comes the name of Pasargadae where lies the tomb of Cyrus the Great.

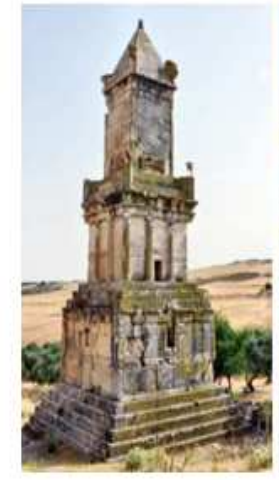

(a)

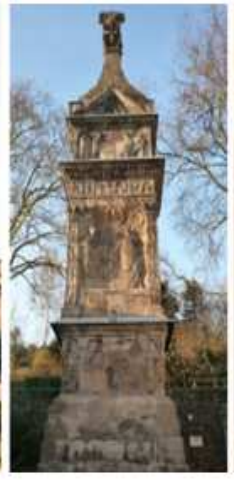

(b)

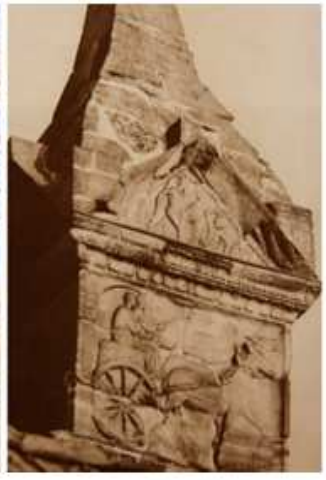

(c)
Figure 3. a) Dougga, Tunisia b) Igel, Germany c) detail with chariot 


\section{Etymology}

Even in central and south Italy, there are toponyms that refer to the properties of the Gens Cassia.

By analyzing the Latin terms that have the prefix "Cass", there are a very few words listed in the Grammatica compiled by Sextus Pompeius Festus [16], or just the following ones:

- Cassiculum, reticulum to cassibus for diminutionem dictum [formerly grid with small grooves so said for shortening] as "a" was used in the abbreviated meaning of antiquo (in this case antiquis), cassibus is a masculine plural ablative (cassis, casside instead is a feminine one and shows a generic helmet, while cassida, cassidae has the meaning of metal helmet). So Cassiculum indicated a network of small paths, cassis, network). We have an example along the roads network which connecting Alba Fucens and Rieti with Otricoli bridge: here from which you reached the via Cassia at Sutri, with the street gutter made of tuff.

- Caseus to coeundo dictus [Caseus, once used to say coeundo] (coeundo comes from coeo, which is the verb assuming multiple meanings: 1) to go or come together, come together, assemble, convene, meet, gather 2) to approach with hostile intent, come to quarrel, fight, 3) form an alliance)

- Cassilam antiqui pro casside ponebant [Cassilam, our ancestors used this term for a helmet, see the Riace bronzes helmets in Figure 2] and this explains well why the words cassis, casside, in Latin, became feminine, in later centuries]. And a galea was a Roman soldier's helmet.

- Cassabundus, crebo credens. Cassabundus, as Festus mentions, means "crebo credens". The word crebo is revealed to be a sure error of transcription and in the ancient incunabula was certainly a shortened word: creberrime. The meaning of "crebe. credens " is "frequently giving faith" and it is also the only logical explanation given by Sextus Pompeius Festus, since in ancient time, there were no traffic signals and therefore, it was necessary to continually seek to establish the direction to take. From cassabundus comes our usual word "wanderer", because the neutral cassus, cassa, cassum, means "empty, vain, useless."

- Castellarius, a few "castles" remain in Italy but all share this particular characteristic: the villages (such as Brienza in the province of Potenza) appear according to a centripetal winding model and naturally centered on a fortress or a castle, which is placed on top of a hill whose slopes intertwine and wriggle out a myriad of perspectives and concentric bands of houses clinging precariously to the steep rock. Another similar example is Arcola in the Province of La Spezia. The organization of the country, called "pagense" (from the Latin word "pagus" meaning village), was accurate and planned for the collection of transit tolls: road maintenance was secured and monitored to avoid the presence of wild beasts and robbers, thus ensuring the travelers to transit safely: the small groups of houses (the Latin term is "vicus") were gathered in specific districts ("pages"), which referred to the "castles", always located in dominant positions and prevalent defensive functions.

\section{Gallia Togata Road Network}

Essentially, the pre-roman country was organized to equidistant points located at a distance from each other always between 30 and $35 \mathrm{~km}$ (example: Cavaglià $<=29 \mathrm{~km}$ $=>$ Vercelli $<=35 \mathrm{~km}=>$ Vigevano $<=30 \mathrm{~km}=>$ Milan (Duomo) $<=29 \mathrm{~km}=>$ Cassano d'Adda $<=31 \mathrm{~km}=>$ Urago d'Oglio (location called Montagnina dei Frati) $<=31 \mathrm{~km}=>$ Brescia). The "castles", later called Castrum, for the protection of the points of tolls collection, were usually placed exactly in the middle and - in the area between Bergamo and Brescia - the town called Castrezzato is an example. Throughout the country of the gens Cassia was organized on this pattern: we can mention as further example, the route Milan - Avignon, itinerary, which shall remain in use until late 1500: Milan $<=30 \mathrm{~km}=>$ Vigevano $<=35 \mathrm{~km}$ $=>$ Casale Monferrato $<=35 \mathrm{~km} \Rightarrow$ Asti (roman "Municipium" known as Hasta Pompeia) $<=30 \mathrm{~km}=$ Chieri (the Roman toponym of Carrea Potentia, handed down by Pliny the Elder) $<=35 \mathrm{~km}=>$ Avigliana (in Latin Villiana which was, in Roman times, the boundary between the ager taurinensis, point of toll collection called quadragesima galliarumt, namely the toll on goods coming from Gaul).

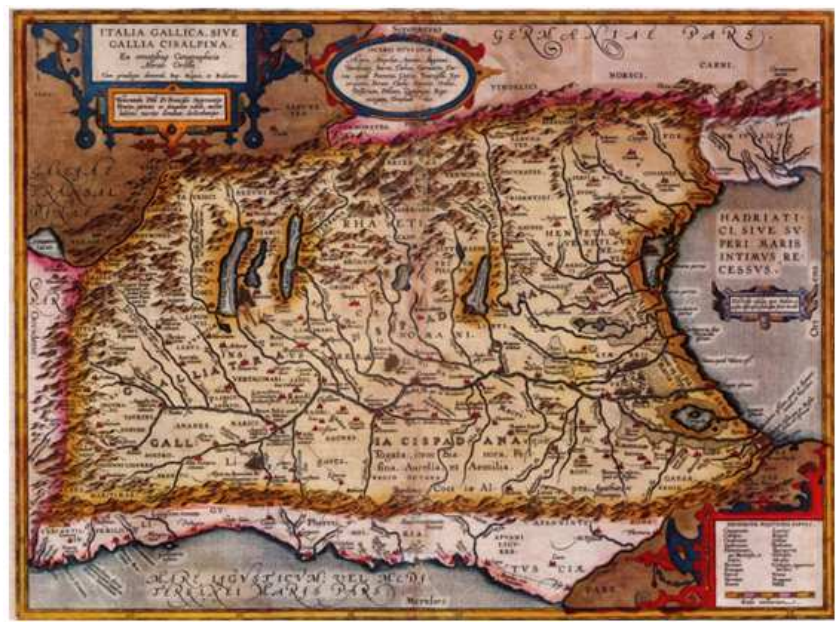

Figure 4. Gens Cassia or rather Gallia Togata

\section{Conclusions}

An immense area was similarly organized, up from Spain to Asia and from northern Europe to Africa. We find traces about that in toponyms and vocabulary of many languages.

Urban systems based, therefore, on the average distance of the slow trading traffic of carts. A perfect system, ante litteram, of central places, according to a regular grid based - 
centuries later - on what is known as a Christaller central place theory.

\section{References}

[1] M. Tulli Ciceronis "Orationes in Catilinam"

[2] P. Villani, "Strade ed epigrafi: attribuzioni corrette" [Roads and epigraphs: correct attributions] in Progettando Ing, Magazine of the Order of Engineers of the Province of Flor-ence, Firenze, September 2009 (references)

[3] G. Da Rios, P. Villani, "I primi itinerari della civiltà" [The first route of civilization], Strade\&Autostrade n.4 July-August 2008, n.70 anno XII, pag.15-22, Milano, 2008

[4] Cataldo Jannelli, "Tentamen hermeneuticum in etruscas inscriptiones eiusque fundamenta proposita", Napoli: ex Re-gia Tipografia, 1840 (references)

[5] Strabonis "Geographica", Lutetiana, Paris, 1620 (references)

[6] A. Pégorier, 'Les nomes des lieux en France', IGN, Paris, 2006 (references)

[7] Felice de Chaurand, O. Marinelli, "Toponimi del comune di Sforzatica", "L'Universo", anno VI, N. 8, Agosto 1925 (references)

[8] Joannes Georgius Graevius, "Thesaurus antiquitam et histo-riarum Italiae", 1704 (references)
[9] G. Da Rios, P. Villani "Le strade dell'impero romano" [The streets of the Roman Empire], Strade\&Autostrade n.5 Sep-tember-October 2008, n.71 anno XII, pag.2-11, Milano, October 2008

[10] P. Villani " Re-theorisation of the Roads Heritage " Archaeology 2013, DOI: 10.5923/j. ID: 105600012 (references)

[11] William Staugthon, "The works of Virgil, with the Latin interpretation of Ruæus, and the English notes of Davidson. To which is added a large variety of botanical, mythological, and historical notes", Baltimora, 1813 (references)

[12] Carlo Peonis, "Le Antichita di Albe Fucense negli Equi misurate ed illustrate", Roma, 1836

[13] Commentarii de Bello Gallico (references)

[14] Michele Tenore, "Flora medica universale, e flore particolare della provincia di Napoli" Napoli, 1823

[15] Olinto Marinelli, "Atlante dei tipi geografici", Istituto Geografico Militare, Roma, 1922

[16] Sextus Pompeius Festus, "De verborum significatione "

[17] Bayet Jean, Georges Dumézil "Naissance de Rome (Jupiter Mars Quirinus, II" in Revue de l'histoire des religions, tome $133 n^{\circ} 1-3,1947$. pp. 192-194

[18] Georges Dumézil, "Gods of the ancient Northmen", University of California Press, 1973. 